\title{
Faktor Kesulitan Menulis Sakubun Mahasiswa Program Studi Pendidikan Bahasa Jepang Universitas Negeri Padang
}

\author{
Intan Permata Sari ${ }^{1}$, Hendri Zalman ${ }^{2}$ \\ ${ }^{1}$ Mahasiswa Pendidikan Bahasa Jepang, Bahasa dan Sastra Inggris, Fakultas Bahasa dan \\ Seni, Universitas Negeri Padang), Jl. Prof. Dr. Hamka Air Tawar, Padang 25131 \\ ${ }^{2}$ Dosen Pendidikan Bahasa Jepang, Bahasa dan Sastra Inggris, Fakultas Bahasa dan Seni, \\ Universitas Negeri Padang ), Jl. Prof. Dr. Hamka Air Tawar, Padang 25131
}

Email Penulis: intan.roshan22@gmail.com

\section{Sejarah Artikel \\ Submit : 2020-10-07 \\ Diterima : 2021-02-19}

Diterbitkan : 2021-06-08

\section{Keywords:}

Factors, Dificulty, Writing, Sakubun (Japanese writing)

\begin{abstract}
This paper of the results of the preliminary study given to students who have difficulty writing sakubun (japanese vocabulary) This study aims to: describe the factors that cause difficulty in writing sakubun (japanese vocabulary) with two factors of difficulty (1) factors in terms of composition with four indicators (a) difficulty in making essay framework (b) difficulty in writing process (c) difficulty in determining the type of essay (d) difficulties in determining the plot of essays and (2) factors from a linguistik perspective with four indicators (a) difficulties related to letters (b) difficulties related to vocabulary (c) difficulties related to sentences (d) difficulties using various languages. This research is a combined research (mix method) with descriptive methods. The data from this study is the dificulty of students writing sakubun (japanese vocabulary), while the data source was taken from the results of a questionnaire distributed to 32 students of the Japanese language education study program Padang State University as many 24 statements. This study uses a closed questionnaire distributes using google form. The result of this study are the factors of composition (essay framework, writing process, type of essay, plot of essays) difficulty factors exist in all aspects (except type of essays) and linguistik factors (letters, vocabulary, sentences, various languages) difficulty factors exist in all aspects.
\end{abstract}

\footnotetext{
${ }^{1}$ Mahasiswa Prodi Pendidikan Bahasa Jepang FBS UNP lulus pada tanggal 16-10-2020

2 Dosen Prodi Pendidikan Bahasa Jepang FBS UNP
} 


\section{PENDAHULUAN}

Bahasa merupakan suatu kemampuan yang harus manusia miliki guna untuk berkomunikasi dengan manusia lainnya dan alat komunikasi penyampaian yang telah banyak berkembang dari zaman ke zaman. Dalam Kamus Besar Bahasa Indonesia (2008:137) bahasa merupakan sistem lambang bunyi konvensionaldan beratikulasi yang dipakai sebagai alat komunikasi untuk melahirkan perasaan dan pikiran. Menurut Sutedi (2011:2) bahasa adalah alat untuk menyampaikan suatu keinginan dan pikiran kepada orang lain. Bahasa juga merupakan bagian penting dalam kehidupan yang di dalam perkembangan kebudayaan manusia sehingga dari itu pelu dan penting untuk dipelajari, baik secara formal ataupun secara non-formal.

Secara formal, bahasa yang diajarkan saat berada di pendidikan menengah dan pendidikan perguruan tinggi tinggi terdiri dari: bahasa ibu (bahasa Indonesia) dan bahasa asing. Alim (2014:2) menyatakan bahwa bahasa Jepang termasuk salah satu bahasa asing yang terbilang baru saat ini dibandingkan bahasa asing lainnya, seperti bahasa Inggris dan Bahasa Arab yang diajarkan di Indonesia.Meskipun terbilang baru dibanding bahasa Inggris dan Arab, bahasa Jepang merupakan salah satu bahasa asing yang banyak dipelajari saat ini, khususnya pada tingkat Sekolah Menengah Atas dan Kejuruan.

Dalam pembelajaran bahasa Jepang dikelompokkan pada kompetensi yang ditetapkan kurikulum, ialah: aspek kognitif, aspek psikomotor, dan aspek afektif (kurikulum 2013). Pada kurikulum 2013, aspek kognitifidentikkan dengan aspek pengetahuan yang terdiri dari: huruf (kana dan kanji), kosakata (goi), dan tata bahasa (bunpou). Aspek psikomotor identikkan dengan aspek keterampilan, yang terdiri dari: mendengarkan (kikugino), berbicara (hanasugino), membaca (yomugino), dan menulis (kakugino).

Dari pengetahuan dan keterampilan di atas, kakugino termasuk keterampilan bahasa yang paling sulit dikuasai karena terdapat materi yang cukup banyak seperti: kanji, goi, bunpo, dan kemampuan mengembangkan ide atau gagasan (Zalman 2014:2). Serupa dengan itu, Sutedi (2009:2) mengatakan bahwa ada tiga macam keterampilan menulis pada bahasa Jepang yaitu: menulis kalimat (bunsaku), menulis huruf (kana dan kanji), dan menulis cerita atau karangan (sakubun). Tarigan (2005:8) menulis harus menurut gagasan-gagasan tersusun secara logis diekspresikan dan ditata secara menarik.

Pada Prodi Pendidikan Bahasa Jepang UNP keterampilan menulis diajarkan pada mata kuliah khusus yang disebut sakubun. Menurut Sudjianto (2010:3) sakubun merupakan keterampilan dalam menulis karangan-karangan tertentu, dari menulis kalimat yang sangat sederhana sampai yang lebih kompleks.

Alwasilah (dalam Sutedi 2009:2) menyatakan bahwa kesulitan mengarang ditunjang oleh dua kesulitan pokok, yaitu 1) komposisi yang merupakan cara dan langkah penyajian isi atau cerita karangan berdasarkan alur yang sesuai dengan kebiasaan dan kebudayaan penutur bahasa Jepang. 2) linguistik yang merupakan kemampuan bahasa mulai dari penguasaan huruf, kosakata, ungkapan, aturan gramatikal, dan pola kalimat yang berlaku dalam bahasa.

Sebelumnya peneliti juga telah melakukan studi pendahuluan dengan membagikan angket secara online kepada mahasiswa tahun masuk 2017 Prodi Pendidikan Bahasa Jepang UNP dengan pembelajaran chukyu sakubun kohan, dalam 
studi pendahuluan tersebut peneliti memberikan pertanyaan kepada 32 orang mahasiswa dengan empat pertanyaan diantaranya: 1) Apakah pernah belajar bahasa Jepang sebelumnya ditingkat Sekolah Menengah Atas? 52,3\% memilih pernah 47,6\% belum pernah, 2) Bagaimana belajar bahasa Jepang? ada tiga opsi mudah, sedang, dan sulit $47,6 \%$ sulit, 52,4\% sedang, dan 0\% memilih mudah3) Bagaimana dengan belajar Sakuubunnya? 47,6\% sulit, 52,4\% sedang, dan 0\% memilih mudah 4) Apakah menemukan kesulitan dalam mata kuliah Sakubun? 100\% dari siswa memilih iya yang artinya iya menemukan kesulitan.

Berdasarkan pandangan ahli dan hasil studi pendahuluan berupa angket yang peneliti bagikan kepada mahasiswa UNP di atas diketahui kesulitan dalam menulis sakubun. Oleh karena itu, penelitipun melakukan penelitan dengan judul "Faktor Kesulitan Menulis Sakubun Mahasiswa Program Studi Pendidikan Bahasa Jepang UNP".

Penelitian ini bertujuan untuk mengetahui apa-apa saja faktor-faktor yang menyulitkan mahasiswa dalam menulis sakubun ditinjau dengan dua faktor yaitu faktor komposisi dan faktor linguistik. Manfaat dari penelitian ini diharapkan bermanfaat dalam memberikan informasi mengenai faktor kesulitan menulis karangan atau sakubun khusunya pada mahasiswa bahasa Jepang dan juga sebagai ajuan bagi peneliti selanjutnya yang akan meneliti mengenai faktor kesulitan menulis karangan dengan topik yang sama.

\section{METODE PENELITIAN}

Jenis penelitian ini yaitu penelitian dengan menggunakan metode gabungan mix method) dengan desain explanatory mixed methods designs Creswell (dalam Zalman 2020:4) dijelaskan bahwa jenis desain penggabungan ini karena terdapat perbedaan kedudukan antara data kuantitatif dengan data kualitatif karena data kuantitatif merupakan data primer yang membutuhkan penjelasan sehingga perlu diperkuat dengan data kualitatif. Pendekatan pada penelitian ini menggunakan pendekatan deskripstif. Data dari penelitian ini adalah kesulitan mahasiswa menulis sakubun, sedangkan sumber data diambil dari hasil angket yang dibagikan kepada 32 orang mahasiswa prodi pendidikan bahasa Jepang UNP sebanyak 24 pernyataan.

Intsrumen yang digunakan pada penelitian ini berupa angket untuk mengetahui faktor-faktor kesulitan menulis sakubun mahasiswa tahun masuk 2017, angket tertutup merupakan jenis angket yang digunakan pada penelitian ini menurut Kurniawan (2018:159) angket ini merupakan angket yang terdapat pilihan jawaban yanag ditetapkan dan dimuat oleh si penulis angket tersebut yang mana sebanyak 24 pernyataan dengan jawaban dengan skala likert.

Pengumpulan data digunakan dengan cara membagikan angket berupa pernyataan kepada mahasiswa dengan menggunakan googe form kemudian dilakukan penghitung data hasil angket dengan rumus acuan pada likert setelah itu menentukan interval penilaiannya. 


\section{HASIL DAN PEMBAHASAN \\ Temuan Penelitian}

Berikut disajikan deskripsi data yang diperoleh yang mana mempunyai dua sub indikator yaitu faktor kesulitan menulis sakubun mahasiswa dari segi komposisi dan linguistik. Dibawah ini tabel deskripsi data hasil penelitian dari faktor komposisi dan linguistik

Tabel 1. Deskripsi Data

\begin{tabular}{clc}
\hline \multicolumn{1}{c}{ Aspek } & \multicolumn{1}{c}{ Indikator } & Kriteria \\
\hline & Kesulitan membuat kerangka karangan & Sulit \\
\cline { 2 - 3 } & Kesulitan dalam proses mengarang & Sulit \\
\cline { 2 - 3 } & Kesulitan menentukan jenis karangan & Sedang \\
\cline { 2 - 3 } & Kesulitan menentukan alur & Sulit \\
\cline { 2 - 3 } Komposisi & Rata-rata & Sulit \\
\hline \multirow{3}{*}{ Linguistik } & Kesulitan terkait huruf & Sulit \\
\cline { 2 - 3 } & Kesulitan terkait kata & Sulit \\
\cline { 2 - 3 } & Kesulitan terkait kalimat & Sulit \\
\cline { 2 - 3 } & Kesulitan menentukan ragam bahasa & Sulit \\
\hline
\end{tabular}

Berdasarkan tabel diatas diketahui faktor linguistik dari kesulitan menulis sakubun lebih sulit dibanding dengan faktor komposisi yang mana dari empat indikator tiga diantaranya sulit berbeda dengan faktor linguistik semua indikator berada pada kategori sulit. Berikut dijabarkan hasil deskripsi data berdasarkan faktor komposisi dan linguistik:

\section{a. Faktor Komposisi Kesulitan Menulis Sakubun Mahasiswa}

Terdapat empat indikator faktor komposisi kesulitan menulis sakubun diantaranya: kerangka karangan, proses mengarang, jenis karangan, dan alur karangan. Dapat dilihat pada tabel dibawah

Tabel2. Analisis Data Faktor Komposisi

\begin{tabular}{clccc}
\hline No & Indikator & Skor & Persen & Kategori \\
\hline 1. & Kerangka Karangan & 115,3 & $72,1 \%$ & Sulit \\
\hline 2. & Proses Mengarang & 115,7 & $72,3 \%$ & Sulit \\
\hline 3. & Jenis Karangan & 95 & $59,4 \%$ & Sedang \\
\hline 4. & Alur Karangan & 113 & $70,7 \%$ & Sulit \\
\hline & rata-rata & 109,7 & $68,6 \%$ & Sulit \\
\hline
\end{tabular}

Berdasarkan hasil penelitian diatas pada faktor komposisi berada pada kategori "sulit" namun tidak semuanya berada pada kategori sulit, dapat dilihat bahwa sub indikator kerangka karangan berada dalam kategori sulit. Hal ini menyatakan bahwa mahasiswa tahun masuk 2017 merasa kesulitan dengan kerangka karangan yang ada dalam sakubun pada chukyu sakubun kohan. Kerangka karangan merupakan rencana penulisan yang memuat garis-garis besar dari suatu karangan yang akan ditulis, dan merupakan rangkaian ide-ide yang disusun secara sistematis, logis, jelas, terstruktur, dan teratur. Dalam pembelajaran mata kuliah chukyu sakubun kohan mahasiwa harus dituntun untuk mengetahui tentang kerangka karangan. 
Pada sub indikator proses mengarang berada dalam kategori "sulit". Hal ini menyatakan bahwa mahasiswa tahun masuk 2017 merasa kesulitan dengan proses mengarang yang ada dalam sakubun pada chukyu sakubun kohan. Proses mengarang merupakan langkah-langkah dalam pengungkapan gagasan, ide, angan-angan, dan perasaan yang disampaikan dalam bentuk tulisan. Proses mengarang tidak diajarkan pada matakuliah khusus maka mahasiswa seharusnya lebih rajin berlatih karena sangat berdampak dalam membuat karangan teks bahasa Jepang.

Pada sub indikator menentukan jenis karangan berada dalam kategori sedang. Hal ini menyatakan bahwa mahasiswa tahun masuk 2017 merasa tidak begitu sulit dan tidak begitu mudah dengan menentukan jenis karangan yang ada dalam sakubun pada chukyu sakubun kohan. Pada tingkatan chukyu sakubun kohan ini sedang dalam menentukan jenis karangan karena jenis karangan yang ada tidak begitu sulit untuk dipahami. Terkait menentukan jenis karangan terdiri dari: perbedaan jenis karangan yang mana artinya mahasiswa tidak dapat membedakan antara jenis karangan deskripsi, narasi, argument yang mengakibatkan pada hasil tulisan serta membuat karangan berdasarkan jenis yang tidak mengakibatkan percampuran antara jenis karangan satu dengan yang lain dalam satu tulisan karangan dan memahami jenis karangan.

Pada sub indikator menentukan alur karangan berada dalam kategori sulit. Hal ini menyatakan bahwa mahasiswa tahun masuk 2017 merasa kesulitan dengan menentukan alur karangan yang ada dalam sakubun pada chukyu sakubun kohan. Alur karangan sering disebut plot yang merupakan unsur intrinsik dalam sebuah tulisan yang menyajikan informasi.

\section{b. Faktor Linguistik Kesulitan Menulis Sakubun Mahasiswa}

Terdapat empat indikator faktor linguistik kesulitan menulis sakubun diantaranya: huruf kanji, kata, kalimat, dan ragam bahasa. Dapat dilihat pada tabel dibawah

Tabel 3. Analisis Data Faktor Linguistik

\begin{tabular}{clccc}
\hline No & \multicolumn{1}{c}{ Indikator } & Skor & Persen & Kategori \\
\hline 1. & Huruf Kanji & 114,7 & $71,7 \%$ & Sulit \\
\hline 2. & Kata & 107,7 & $67,3 \%$ & Sulit \\
\hline 3. & Kalimat & 117,3 & $73,4 \%$ & Sulit \\
\hline 4. & Ragam Bahasa & 116 & $72,5 \%$ & Sulit \\
\hline \multicolumn{2}{r}{ Rata-rata } & 113,9 & $71,2 \%$ & Sulit \\
\hline
\end{tabular}

Berdasarkan hasil penelitian diatas pada faktor linguistik berada pada kategori "sulit" dan semua indikator berada pada kategori sulit dapat dilihat bahwa sub indikator kanji berada dalam kategori "sulit". Hal ini menyatakan bahwa mahasiswa tahun masuk 2017 merasa kesulitan dengan huruf kanji yang ada dalam chukyu sakubun kohan. Kanji merupakan huruf yang sulit untuk di hafal karena memiliki cara baca yang lebih dari satu (on yomi dan kun yomi), banyaknya variasi kanji dan juga memiliki bentuk dengan coretan (kakusuu) yang banyak dan rumit yang membuat sulit untuk dibaca.

Pada sub indikator menentukan kata berada dalam kategori "sulit". Hal ini menyatakan bahwa mahasiswa tahun masuk 2017 merasa kesulitan dengan kata dalam sakubun pada chukyu sakubun kohan. Kata merupakan rangkaian atau susunan beberapa huruf. 
Pada sub indikator menentukan kalimat berada dalam kategori "sulit". Hal ini menyatakan bahwa mahasiswa tahun masuk 2017 merasa kesulitan dengan kalimat dalam sakubun pada chukyu sakubun kohan. Kalimat merupakan bagian penting dari tulisan yang mana kalimat bahasa Jepang diajarkan pada matakuliah bunpo didalamnya mengajarkan pola kalimat dan partikel. Pada tingkatan chukyu sakubun kohan ini banyaknya yang sulit dalam menentukan kalimat karena masih banyak mahasiswa yang ragu dengan penggunaan kalimat yang tepat.

Pada sub indikator ragam bahasa berada dalam kategori "sulit". Hal ini menyatakan bahwa mahasiswa tahun masuk 2017 merasa kesulitan dengan ragam bahasa dalam sakubun pada chukyu sakubun kohan. Ragam bahasa merupakan bentuk bahasa yang bervariasi menurut konteks pemakaian yang berbeda-beda menurut situasi. Pada tingkatan chukyu sakubun kohan ini banyaknya yang sulit dalam menentukan ragam bahasa karena masih banyak mahasiswa yang ragu dengan penggunaan ragam bahasa yang tepat.

\section{Pembahasan}

Berdasarkan deskripsi data dan analisis data angket faktor kesulitan menulis sakubun mahasiswa tahun 2017 JPG 1 prodi pendidikan bahasa Jepang UNP angket faktor kesulitan menulis sakubun ini disusun berdasarkan dari faktor segi komposisi kesulitan membuat kerangka karangan, dalam proses mengarang, menentukan jenis karangan, alur karangan dan faktor linguistik kesulitan terkait huruf kanji, kata, kalimat dan ragam bahasa yang masing-masing memiliki tiga pernyataan.

Berdasarkan persentase hasil penelitian faktor kesulitan dari segi komposisi dengan indikator(1) kesulitan dalam membuat kerangka karangan memiliki rata-rata sebesar $72,1 \%$, (2) kesulitan dalam proses mengarang memiliki rata-rata sebesar $72,3 \%$, (3) kesulitan dalam menentukan jenis karangan memiliki rata-rata 59,4\%, (4) kesulitan dalam menentukan alur memiliki rata-rata 70,7\%, sedangkan dari segi linguistik dengan indikator (1) kesulitan terkait huruf kanjimemiliki rata-rata 71,7\%, (2) kesulitan terkait kata memiliki rata-rata 67,3\%, (3) kesulitan terkait kalimat memiliki rata-rata $73,4 \%$, (4) kesulitan terkait ragam bahasa memiliki rata-rata $72,5 \%$.

Pada segi komposisi yang terdiri dari empat indikator (1) kerangka karangan dengan pernyataan (a) saya kesulitan dalam membuat kerangka karangan sebelum mengarang bahasa Jepang 71\% kategori "sulit" (b) saya kesulitan dalam menyusun kerangka karangan yang sesuai tema 73,8\% (c) saya kesulitan dalam mengumpulkan bahan-bahan untuk kerangka karangan $71,3 \%$. (2) proses mengarang dengan pernyataan (a) saya kesulitan dalam memulai proses mengarang $77,5 \%$ (b) saya kesulitan dalam menghubungkan kalimat-kalimat yang koheresi antara satu paragraf dengan paragraf lain $73,1 \%$ (c) saya kesulitan dalam menulis penutup karangan yang tepat $66,3 \%$. (3) jenis karangan dengan pernyataan (a) saya kesulitan mengetahui perbedaan jenis karangan $66,3 \%$ (b) saya kesulitan membuat karangan berdasarkan jenis $51,3 \%$ (c) saya kesulitan memahami jenis karangan 60,6\%. (4) alur karangan dengan pernyataan (a) saya kesulitan menentukan alur karangan $74,4 \%$ (b) saya kesulitan menyusun kalimat-kalimat sesuai alur $71,3 \%$ (c) saya kesulitan menyinkronkan alur karangan $66,3 \%$. 
Segi linguistik terdiri dari empat indikator (1) huruf kanji dengan pernyataan (a) saya kesulitan menulis huruf kanji $73,1 \%$ (b) saya kesulitan dalam memilih huruf kanji (c) saya kesulitan dalam memilih kanji yang tepat 71,9\%. (2) terkait kata dengan pernyataan (a) saya kesulitan menggunakan kosakata yang diberikan 61,3\% (b) saya kesulitan dalam memilih kata yang tepat $70 \%$ (c) saya kesulitan memilih perubahan kata yang tepat $70,7 \%$. (3) terkait kalimat dengan pernyataan (a) saya kesulitan dalam membuat kalimat berdasarkan pola kalimat $60,4 \%$ (b) saya kesulitan dalam memilih partikel yang tepat $78,8 \%$ (c) saya kesulitan menerjemahkan kalimat bahasa Jepang $71,9 \%$ (4) ragam bahasa dengan pertanyaan (a) saya kesulitan memahami perbedaan ragam bahasa tulis dan lisan $72,5 \%$ (b) saya kesulitan menggunakan ragam bahasa $72,5 \%$ (c) saya kesulitan menentukan ragam bahasa $72,5 \%$.

Dari hasil persentase di atas bahwa faktor kesulitan menulis sakubun dari segi komposisi tingkat kesulitannya rata-rata 68,6\% sedangkan faktor kesulitan dari segi linguistik $71,2 \%$ yang berarti kesulitan menulis sakubun dari segi linguistik lebih tinggi sedikit dibandingkan dari fakor komposisi. Namun dari keseluruhan pernyataan dari angket yang telah dibagikan pernyataan yang paling sulit menurut responden ialah "saya kesulitan dalam memilih partikel yang tepat (ketika ada partikel yang fungsinya mirip)" dan "saya kesulitan membuat karangan berdasarkan jenis karangannya" merupakan pernyataan yang paling rendah.

Hasil penelitian ini sama dengan penelitian relevan dari Janah (2013) dengan judul "Analisis Kesulitan Mengarang Mahasiswa Prodi Pendidikan Bahasa Jepang Angkatan Tahun 2009 UNNES" dengan dua faktor kesulitan segi komposisi dan linguistik yang hasilnya diperoleh bahwa penelitian ini dan Janah sama-sama kesulitan pada faktor linguistik pada sub indikator kalimat (pola kalimat) dan ragam bahasa. Kalimat atau pola kalimat merupakan rangkaian kata yang mengungkapkan gagasan dan perasaan. Menurut Sutedi (2009:138) bahasa asing lain selain bahasa Jepang memiliki struktur pola kalimat dengan "subjek + verba + objek $(\mathrm{S}+\mathrm{V}+\mathrm{O})$ verba selalu terletak diakhir kalimat sedangkan bahasa Jepang memiliki struktur pola kalimat "subjek + objek + verba $(\mathrm{S}+\mathrm{O}+\mathrm{V})$ " karena ini yang membuat pola kalimat bahasa Jepang sulit. Kesulitan pada pola kalimat dari hasil penelitian ini disebabkan karena pada pola kalimat setiap materi pembelajar selalu mendapatkan pola kalimat baru akhirnya hanya memahami dan menerapkan pola kalimat pada saat pelajaran saja setelah itu jarang digunakan lagi. Kesulitan pada ragam bahasa tulis disebabkan karena pemahaman awal pembelajar tentang perbedaan ragam bahasa lisan dan ragam bahasa tulis kurang dan juga pemakaian yang mereka gunakan juga kurang.

Dari hasil penelitian dan analisis yang telah peneliti lakukan terdapat keunikan yang mana dari kedua faktor yang ada faktor komposisi dan faktor linguistik kesulitan paling tinggi ada pada faktor linguistik dengan hasil 71,2\% dengan kategori "sulit" dibandingkan dengan faktor komposisi yang seharusnya responden atau pembelajar lebih memahami faktor linguistik karena semua aspek atau indikator yang ada pada linguistik sudah dipelajari pada matakuliah khusus seperti: bunpou, kanji, moji goi dan sedangkan dari faktor komposisi seperti: alur karangan, jenis karangan, proses mengarang, dan kerangka karangan itu tidak diajarkan pada matakuliah manapun tetapi hasilnya lebih rendah dari faktor linguistik 
dan dari keempat indikator ada satu indikator yang menurut responden tidak sulit masuk dalam kategori "sedang".

\section{KESIMPULAN}

Berdasarkan hasil persentase di atas dapat diambil kesimpulnya bahwa kesulitan menulis sakubun mahasiswa tahun masuk 2017 mengalami kesulitan dengan kriteria rata-rata ialah "sulit", faktor kesulitan menulis sakubun dari segi komposisi tingkat kesulitannya rata-rata 68,6\% sedangkan faktor kesulitan dari segi linguistik $71,2 \%$ yang berarti kesulitan menulis sakubun dari segi linguistik lebih tinggi sedikit dibandingkan dari fakor komposisi. Namun dari keseluruhan pernyataan dari angket yang telah dibagikan pernyataan yang paling sulit menurut responden ialah "saya kesulitan dalam memilih partikel yang tepat (ketika ada partikel yang fungsinya mirip)" dengan $78,8 \%$ kategori "sulit" hampir mendekati sangat sulit dan "saya kesulitan membuat karangan berdasarkan jenis karangannya" merupakan pernyataan yang paling rendah dengan kategori "sedang" sebanyak $51,3 \%$.

Jadi hasil analisis data yang telah dilakukan dari delapan faktor kesulitan yang ada tujuh diantaranya mengalami kesulitan dari faktor komposisi: kerangka karangan, proses mengarang, alur karangan dan jenis karangan tidak mengalami kesulitan dengan kriteria sedangkan dari faktor linguistik mengalami kesulitan pada semua indikator: terkait huruf, terkait kata, terkait kalimat, dan ragam bahasa. Oleh karena itu, faktor kesulitan menulis sakubun mahasiswa program studi pendidikan bahasa Jepang Universitas Negeri Padang mengalami kesulitan pada tujuh indikator yang telah dijabarkan di atas.

\section{REFERENSI}

(2018). Kamus Besar Bahasa Indonesia (KBBI).Jakarta: PT Gramedia Pustaka Umum.

Alim, Burhanuddin. 2014.Ayo Belajar Bahasa Jepang. Yogyakarta: Graha Ilmu.

Janah, Zuraida Nurul. 2011. Analisis Kesulitan Mengarang Mahasiswa Program Studi Pendidikan Bahasa Jepang Angkatan Tahun 2009 UNNES.Skripsi.Surakarta: UNNES.

Kurniawan, Asep. 2018. Metodologi Penelitian Pendidikan. Bandung: PT Remaja Rosdakarya.

Sudjianto \& Ahmad Dahigi. 2010. Pengantar Linguistik Bahasa Jepang. Bekasi Timur: KBI.

Sugiyono. 2017. Metode Penelitian Kuantitatif Kuaitatif dan RD. Bandung: IKAPI.

Sutedi, Dedi. 2009. Penelitian Pendidikan Bahasa Jepang. Bandung : UPI Press. .2009. "Beberapa Alternatif untuk Mengatasi Masalah dalam Pembelajaran Sakubun”.Jurnal Pendidikan Bahasa Jepang ASPBJI Korwil Jabar, Vol. 2, No.2. edisi Desember 2009.

2011. Dasar-dasar linguistik bahasa Jepang (edisi revisi). Bandung: Anggota IKAPI.

Tarigan, Henry Guntur. 2005. Menulis Sebagai Suatu Keterampilan Berbahasa. Bandung: Angkasa. 
Widianingsih.2009. Efektivitas Penggunaan Metode Imajinative LearningTerhadap Kemampuan Menulis Sakubun Tingkat Dasar.Skripsi: FPBS UPI Bandung.

Zaim, M. 2014. Metode Penelitian Bahasa. Padang: FBS UNP Press.

Zalman, Hendri. 2014. Shokyu Sakubun. Buku belum diterbitkan. Padang: Universitas Negeri Padang. ..http://scholar.google.co.id. Diakses pada 28 Agustus 2020. 